\title{
Zero Calculated Ambiguity: Unconditional Security Assurances for NWFZ-States Limit the Space for Deterrence
}

\author{
Tarja Cronberg \\ Stockholm International Peace Research Institute, Stockholm, Sweden
}

Email address:

cronberg@sipri.org

\section{To cite this article:}

Tarja Cronberg. Zero Calculated Ambiguity: Unconditional Security Assurances for NWFZ-States Limit the Space for Deterrence. Journal of Political Science and International Relations. Vol. 4, No. 3, 2021, pp. 102-111. doi: 10.11648/j.jpsir.20210403.15

Received: May 25, 2021; Accepted: August 16, 2021; Published: August 31, 2021

\begin{abstract}
Calculated Ambiguity is a policy applied by the nuclear weapon states on negative security assurances given to the non-nuclear states. The goal of these assurances is to guarantee that states that have abstained from nuclear weapons will not be attacked by these weapons. The article demonstrates how these assurances have been watered down since the negotiations of the Non-Proliferation Treaty, the NPT, in the 60s. In "Renegotiating the Nuclear Order: A Sociological Approach" I have applied the "sociology of technology" in order to understand the non-nuclear states' potential policies to counter this trend. As a result the study focuses on states that belong to the nuclear weapon-free zones (NWFZ-states). These states have a treaty-based commitment to a nuclear weapon-free status and the nuclear weapon states are, in a protocol to the treaties, required to confirm this status and to refrain from nuclear attacks. As ambiguity is built into these assurances the article explores a process by which the NWFZ-states, by walking out of a NPT Review Conference, could achieve unconditional guarantees. The case of the "Mexican amendments" from the early NPT-negotiations is selected as a parallel example to empower the NWFZ-states for collective action. Nevertheless, this implies that the NWFZ-states be organized, not only regionally, but also globally. The article concludes with a comment on how these unconditional assurances could form a critical step towards a nuclear weapon-free world.
\end{abstract}

Keywords: NPT, Deterrence, Calculated Ambiguity, Negative Security Guarantees, NWFZ-states, Mexican Amendments, Nuclear-free Status, Nuclear Weapon-free World

\section{Introduction}

The current debate on nuclear disarmament is polarized. The nuclear states and their allies insist on security policies that rely on nuclear deterrence. Their focus is on how to prevent risks related to nuclear use. No-First-Use and dealerting policies are widely-debated. An alternative is presented by the Treaty on the Prohibition of Nuclear Weapons [1], a treaty that has now entered into force. The proponents claim that the only way to reduce nuclear risks is to eliminate nuclear weapons.

This article presents a third approach. If there are fewer states that can legally be attacked by nuclear weapons, this not only reduces the risk of nuclear weapon use but also reduces the attractiveness of nuclear weapon possession. Unconditional and legally-binding negative security guarantees is a tool to gradually limit (and with time reduce to zero) the geographic area available for nuclear deterrence policies. The more countries that have these guarantees, the less geographic space is there available for nuclear threats.

Nuclear weapons should not be used against states that have abstained from these weapons. This compensation for abstinence, officially called "negative security assurances" [2] has been on the nuclear tables since the early negotiations of the Nuclear Non-Proliferation Treaty. However, the examples are few and none unconditional, nor accepted as legally binding. Making these assurances unconditional and legally binding at the same time increasing their reach over larger and larger geographic areas of the world will limit the possibilities of nuclear weapon use at the same time providing strategic protection and security for the states abstaining. The feasibility of the approach is fundamentally 
based on whether calculated ambiguity at the core of deterrence can be reduced. Consequently, the article first analyses the role calculated ambiguity plays for deterrencebased security.

Next the article follows the historical emergence of the negative security assurances and demonstrates how more and more exceptions undermine the credibility of these guarantees making insecurity related to abstinence more and more likely. Nevertheless, the "Mexican amendments" of 1968 provide some indication of what is possible and raises the question of possible counterstrategies by states in the nuclear weapon-free zones (NWFZ-states). ${ }^{1}$ Would they have the political leverage to pressure the nuclear weapons states to approve unconditional and legally binding assurances, and if so how?

A further question is, how to expand these guarantees to cover also the states currently outside these zones. A Middle East zone free of nuclear weapons has been in the making for a long time, as has the nuclear weapon-free zone for Europe. Models for these are being developed, and one exists even for North-East Asia. Mongolia's example as a single-state nuclear weapon-free zone may also serve as an example. Finally, the ultimate question deals with the superpowers. What would be their role in a world consisting increasingly of nuclear weapon-free zones with unconditional and legally binding security assurances?

\section{Calculated Ambiguity: The Core of Deterrence}

Nuclear deterrence is about threats, not about nuclear use. Nevertheless, the threat to use nuclear weapons, even if it does not take place, has to be credible for those targeted. Nuclear deterrence is explicitly justified, not by your own policy-makers believing that an attack will be successfully carried out, but by others believing. Thomas Schelling, who developed the deterrence theory, explains this as the "rationality of irrationality" [3]. He argues that the rationality of nuclear deterrence does not rest on whether or not it is rational to carry out a nuclear attack, but rather on whether or not it is rational to make your opponent believe that you will do so. Essentially, deterrence is uncertainty in the mind of a potential adversary.

The rationality of irrationality, in turn, implies that the situations when nuclear weapons might be used tend not be clearly defined. The threat against the adversary has to be credible and the adversary's fear has to be real. The fear of a nuclear attack is created by their catastrophic consequences, by their sheer numbers, by the surprise effect of their potential use and even by the speed by which the attack takes place. To define, in which situations an attach will not take place, goes against the basic principle of nuclear deterrence. Consequently, nuclear weapon states do not want to openly

1 For the history and assessment see Goldblat, Jozef (1997) "Nuclear-weaponfree zones: A history and assessment", The Nonproliferation Review, Volume 4, Issue 3, pp. 18-32. limit their options of use, not only against their current adversaries but also against any potential future adversary.

Calculated ambiguity becomes an essential dimension of any nuclear threat. Furthermore, a nuclear weapon state does not need a concrete enemy, when defining nuclear attacks. States like the UK base their nuclear deterrence on a potential future adversary and the nuclear policy is one of fighting possible future adversaries. ${ }^{2}$ A state like France has built a nuclear defense, not against a concrete enemy, but to guarantee its autonomy and prevent any nuclear blackmail and coercion. ${ }^{3}$ Furthermore, it is argued that nuclear deterrence is the last choice if non-nuclear deterrence is not enough. Consequently, nuclear deterrence is necessary for any potential current or future adversary, both nuclear and non-nuclear. And finally, nuclear threats against adversaries create a global security atmosphere based on fear which enforces the credibility of deterrence.

In my analysis in "Renegotiating the Nuclear Order: A Sociological Approach" [4] I have looked at the different groups of nuclear and non-nuclear states to see, which group would be able to implement this strategy of "limiting the space for deterrence". The group able to do this consist of the states in nuclear weapon-free zones, here called NWFZ-states. These states have not only abstained but have a double commitment to a nuclear-free status, firstly internationally as parties to the NPT-treaty, secondly regionally as parties to their regional zone-treaty.

\section{The Conditionality of Security Assurances}

During the negotiations of the Nuclear Non-Proliferation Treaty in the in the $60 \mathrm{~s}$, it would have been a natural bargain to guarantee that states abstaining would under no conditions be attacked by nuclear weapons [5]. Nevertheless, the treaty does not include any negative security assurances although President Lyndon Johnson, on October 16, 1964, made the pledge that "the nations that do not seek national nuclear weapons can be sure that, if they need our strong support against some threat of nuclear blackmail, then they will have it" [5].

In 1968, when the NPT-treaty was approved, the U.S., the USSR and the UK gave, in the form of a UN resolution, vague positive security assurances to the non-nuclear states. They would, if a NPT-state was under nuclear threat or aggression provide assistance to the state. The nature of the assistance was not defined, the resolution talked about

2 The U.K. has no defined adversary but sees nuclear deterence as an insurance policy for the future. The December 2006 White Paper summary states: "The future is uncertain: accurately predicting events over the period 2020 to 2050 is extremely hard. There are worrying trends: nuclear non-proliferation continues; large nuclear arsenals remain, and some are being enlarged and modernised; and there is the potential risk from state-sponsored terrorists armed with nuclear weapons."

3 For a description of the French model see Sagan, Scott D. (1996-1997) "Why Do States Build Nuclear Weapons? Three Models in Search of a Bomb", International Security, 21: 3, 54-86. 
support in general terms. These so called "positive security assurances" actually implied that the non-nuclear states could be targeted with nuclear weapons. ${ }^{4}$

More serious action followed in 1995, at the time when the continuation of the NPT was up for a decision. In 1995 the P5 issued individual statements that they would not use nuclear weapons against states that had agreed in binding international agreements to abstain [6]. But these statements were not unconditional. The UK, the U.S., Russia and France had formulated a common exception, here quoted after the UK formulation:

"except in the case of an attack on the United Kingdom, its dependent territories, its armed forces or its allies by such a State in association or alliance with a nuclear weapon state" [7].

China, in its 1995 statement, reaffirmed in its 2019 White Paper, took a stronger position. China's statement is unconditional:

"China is always committed to a nuclear policy of no first use of nuclear weapons at any time and under any circumstances, and not using or threatening to use nuclear weapons against non-nuclear-weapon states or nuclearweapon-free zones unconditionally" [8].

This unconditional position has often surprised Chinese adversaries, who tend to call its sincerity in this respect into question. $^{5}$

These statements, in the context of the NPT treaty maybe compared, in relation to their calculated ambiguity content to the military doctrines of both Russia and the U.S., where ambiguity prevails. Russia's position has evolved. The official Soviet policy, which was set in the 1970s and confirmed in 1982, allowed for the use of nuclear weapons only in response to a nuclear attack, in fact a no-first use policy. The 1993 Doctrine opened for the first use of nuclear weapons but assigned only one mission to the nuclear arsenal deterrence of a large-scale attack that threatened the sovereignty and the very survival of the country.

The first Russian military doctrine signed by President Putin (2000) expands the first use of nuclear weapons to "other weapons of mass destruction against itself or its allies and also in response to large-scale aggression involving conventional weapons in situations that are critical for the national security of the Russian Federation and its allies."

4 The UN Security Council Resolution 255 from 1968 "recognizes that aggression with nuclear weapons or the threat of such aggression against a nonnuclear-weapon State would create a situation in which the Security Council, and above all its nuclear-weapon State permanent members, would have to act immediately in accordance with their obligations under the United Nations Charter". Further, it "welcomes the intention expressed by certain States that they will provide or support immediate assistance, in accordance with the Charter, to any non-nuclear-weapon State Party to the Treaty on the Non-Proliferation of Nuclear Weapons that is a victim of an act or an object of a threat of aggression in which nuclear weapons are used".

5 As China is modernizing its nuclear arsenal there are doubts whether this policy will hold. See Lowsen, Ben (2018) "Is China Abandoning Its 'No First Use' Nuclear Policy?", The Diplomat, 21 March. Available: https://thediplomat.com/2018/03/is-china-abandoning-its-no-first-use-nuclearpolicy/ [July 2, 2021].
The current doctrine of 2015 confirms this concept but instead of national security talks again about situations "when the very existence of the state is in jeopardy" [9]. There has been a discussion in the West on whether Russia has expanded its first use also to conflict de-escalation ${ }^{6}$.

The details of the use of nuclear weapons are secret in Russia as in all of the nuclear weapon states. However, seldom does anyone so openly disregard the information given to the public as Nikolai Bordyuzha, secretary-general of the Collective Security Treaty Organization (CSTO) who stated about the Russian Military Doctrine of 2000:

"When it comes down to it, the final decision to use or not use nuclear weapons in any crisis of fundamental national interest will be made on the spot and will not be constrained by such published doctrines and public statements."

The U.S. has never had a no-first use policy although this was seriously considered during the Obama administration. Prior to this, the United States had been deliberately vague about whether it would use nuclear weapons in response to a chemical or biological attack, regardless of whether the state had nuclear weapons or was in compliance with its NPT obligations. This doctrine implies that the United States does not take for given that it would not use nuclear weapons in response to a chemical or biological attack, but it would not rule it out.

Already a declassified report from 1995 prepared for U.S. Strategic Command reaffirmed that "we must be ambiguous about details of our response (or preemption) if what we value is threatened, but it must be clear that our actions would have terrible consequences." In 1998 Defense Secretary William Cohen stated: "We think that the ambiguity involved in the issue of nuclear weapons contributes to our own security, keeping any potential adversary who might use either chemical or biological [weapons] unsure of what our response would be. We think it is a sound doctrine."

Given the force of calculated ambiguity, a no-first-use policy was not approved during the Obama presidency although the arguments seemed convincing. According to

6 In 1999 an article in the leading military journal Voyennaya mysl developed the notion that nuclear weapons could be used in order to "de-escalate" a regional war A limited use of nuclear weapons should increase the costs to the attacker sufficiently to outweigh expected political and economic benefits leading to a termination of the conflict. In the end of 1999 the chief of the Russian Strategic Rocket Forces, Vladimir Yakovlev, coined the term "expanded deterrence" to denote the mission of de-escalation of limited conflicts. For more see NTI (1999) Russia's 2000 Military Doctrine, 1 October. Available: https://www.nti.org/analysis/articles/russias-2000-military-doctrine/ [3.7.2021].

The Russian 2000 military doctrine has been interpreted to assert a first use policy with the goal to de-escalate a conflict, for more see Stowell, Joshua (2008) "Escalate to De-Escalate: Russia's Nuclear Deterrence Strategy", Global Security Review, 20 August. Available: https://globalsecurityreview.com/nuclearde-escalation-russias-deterrence-strategy/ [29.12.2018].

7 Quoted after Sagan D. Scott, 2000 ('The Commitment Trap. Why the United States Should Not Use Nuclear Threats to Deter Biological Attacks", International Security Vol. 24.No 4 pp. 85-115) who refers to Priest Dana and Walter Pincus, 1998. ("The US Rejects 'No First Use'Atomic Policy: Nato Needs Strategic Option, Germany Told", Washington Post, November 24, 1998 p. A24). 
Michael Gerson the policy of first use was not only unnecessary, given the U.S. conventional superiority, but also dangerous. He argues that,

"the size and accuracy of the current U.S. nuclear arsenal, and the variation in the nuclear capabilities of current and potential adversaries, the continued option to use nuclear weapons first risks creating instabilities in a severe crisis that increase the chances of accidental, unauthorized, or deliberate nuclear use. In a future crisis with a nucleararmed state, the fear- whether real or imagined - that the United States might attempt a disarming first strike increases the possibility of nuclear escalation" [10].

Furthermore, two former militaries, James Cartwright and Bruce Blaidel, have argued for a no-first-use policy as a costreducing measure. They question the rationale for retaining the large arsenal of land-based strategic missiles in silos across the Midwest and the tactical nuclear weapons deployed in Europe. By scrapping the vulnerable land-based missile force, any need for launch on warning would disappear. Strategic bombers and submarines exert less pressure on decision-makers to fire the weapons quickly. Furthermore, they argue that both bombers and submarines are less vulnerable to cyberwarfare than strategic missiles on land. Consequently, a no-first-use policy would even reduce the risks of accidental or unauthorized use of nuclear weapons.

Cartwright and Blaidel even link the policy to democracy. A no-first-use policy would help ensure that democratically elected officials maintained control over nuclear weapons. Savings from reducing the nuclear force could be invested in fortifying command centers and communications networks, which would better protect the president and ensure the continuity of government during a crisis. On the global level, they believe a no-first-use policy could catalyze multilateral negotiations to reduce nuclear arms, discourage non-nuclear states from developing them and reinforce the Nuclear NonProliferation Treaty [11].

The Obama administration's Nuclear Posture Review, the NPR of 2010, declares that the "fundamental role" of U.S. nuclear weapons is for deterrence. Consequently, it does not include a no-first-use policy. The Strategic Posture Commission, a congressionally mandated committee led by former Defense Secretaries William Perry and James Schlesinger, stated in 2009 that a no-first-use policy would "undermine the potential contributions of nuclear weapons to the deterrence of attack by biological weapons" and would be "unsettling to some U.S. allies" [12].

The latest U.S. Nuclear Posture review of 2018, defines the situations of use and talks about extreme circumstances:

"The United States would only consider the employment of nuclear weapons in extreme circumstances to defend the vital interests of the United States, its allies, and partners. Extreme circumstances could include significant nonnuclear strategic attacks. Significant non-nuclear strategic attacks include, but are not limited to, attacks on the U.S., allied, or partner civilian population or infrastructure, and attacks on U.S. or allied nuclear forces, their command and control, or warning and attack assessment capabilities."

In the 2018 review the U.S. assures that it will not use or threaten to use nuclear weapons against non-nuclear weapons states that are party to the NPT and in compliance with their nuclear non-proliferation obligations. Nevertheless, the United States reserves the right "to make any adjustment in the assurance that may be warranted by the evolution and proliferation of non-nuclear strategic attack technologies and U.S. capabilities to counter these threats". In addition, also the U.S. talks about limiting damage of an attack by using nuclear weapons.

During the lifetime of the NPT the options for nuclear use have expanded from attack in alliance with a nuclear state to WMD-attacks, to non-nuclear strategic attacks and even to limiting damage of any attack. Furthermore, an adjustment of the policy or a doctrine seems to be possible at any time. An example of this the Budapest Memorandum of 1994 guaranteeing the borders of the states that abolished their nuclear weapons after the collapse of the Soviet Union.

\section{The NPT and the Budapest Memorandum}

Not only non-nuclear weapon states have received negative security guarantees. Also, countries that have exited nuclear weapons have received assurances. In December, 1994 a memorandum by the U.S., the UK and Russia affirmed individually to Belarus, Kazakhstan and Ukraine their obligation to refrain from the threat or use of force against the territorial integrity or political independence of these countries.

The Budapest Memorandum on Security Assurances refers to three identical political agreements signed at the OSCE conference in Budapest, Hungary on 5 December 1994, providing security assurances by Russia, the UK and the U.S. ${ }^{8}$ relating to the accession of Belarus, Kazakhstan and Ukraine to the Treaty on the Non-Proliferation of Nuclear Weapons. Nevertheless, even in this memorandum there is an exception, which refers to "self-defence or otherwise in accordance with the Charter of the United Nations." All three states also reconfirmed their commitment not to use nuclear weapons against any non-nuclear NPT state. The three former Soviet states agreed to transfer their nuclear weapons to Russia and to join the NPT, Ukraine being the last in late 1994.

The Budapest Memorandum on Ukraine was in 2014 referred to in the case of Crimea [13]. Russia was seen to be in breach with the agreement having changed Ukrainian borders. Russia has claimed that the situation in Ukraine was revolutionary and the country a different one, one to which Russia had not made any commitments. Accused of also breaking the promise of the security guarantees the U.S. and the UK referred to the guarantees being weak and not legally

8 While the memorandum was originally signed by three nuclear powers, the sponsors of the NPT, the remaining P5 states, China and France, gave somewhat weaker individual assurances in separate statements. 
binding.

\section{Nuclear Weapon-Free Zones (NWFZ)}

118 states are members of the five existing nuclearweapon-free zones. ${ }^{9}$ Covering 39 percent of the world's population, these zones are comprised of states that have voluntarily committed to abstinence and renounced nuclear deterrence in all its forms. They agree not to manufacture, acquire, test, or possess nuclear weapons and to prohibit the development, stationing or testing of nuclear weapons in their respective regions.

No member state has ever withdrawn from a zone and there are no examples of suspicious nuclear-weapon programs by any state party to a zone treaty. All members have signed their IAEA safeguards agreements and compliance may even controlled at the regional level as in the case of Argentine and Brazil. ${ }^{10}$ States in the nuclear weapon-free zones, seem at least during the first 50 years of their existence to be "non-proliferation proof". This is explained by the trust built in the region reaching often over to other sectors than security.

The NWFZ-agreements include annexed protocols for the P5 to sign and ratify. ${ }^{11}$ According to these, each party undertakes not to use or threaten to use a nuclear weapon or other nuclear device against any state of the treaty. The Latin American and the Caribbean (Tlatelolco) treaty is the only one, where this protocol has been ratified by all P5 (see below under Mexican Amendments). In the case of the South Pacific, African and Central Asia treaties all of the P5 except the US have ratified the treaties. The Southeast Asia (Bangkok) treaty has neither been signed nor ratified by any of the P5.

9 The five zones are: Latin America (the 1967 Treaty of Tlatelolco), the South Pacific (the 1985 Treaty of Rarotonga), Southeast Asia (the 1995 Treaty of Bangkok), Africa (the 1996 Treaty of Pelindaba) and Central Asia (the 2006 Treaty of Semipalatinsk), for more see: United Nations Office for Disarmament Affairs (UNODA) (n.d.) Nuclear-Weapon-Free Zones, [Online]. Available: https://www.un.org/disarmament/wmd/nuclear/nwfz / [May 18, 2020] Also, Mongolia's self-declared nuclear-weapon-free status has been recognized internationally through the adoption of a UN General Assembly resolution 55/33S on "Mongolia's international security and nuclear weapon free status", for more see: Nuclear Threat Initiative (NTI) (2020) Nuclear-Weapon-Free Status of Mongolia, April 30. [Online] Available: https://www.nti.org/learn/treaties-andregimes/nuclear-weapon-free-status-mongolia/ [July 20, 2020].

10 The two states established in 1991 the Brazilian-Argentine Agency for Accounting and Control of Nuclear Materials (ABACC) to guarantee Argentina, Brazil, and the international community that all the existing nuclear materials and facilities in the two countries are being used for exclusively peaceful purposes, for more see: ElBaradei, Mohamed (2005) Nuclear-Weapon-Free Zones: Pursuing Security, Region by Region, IAEA Director General Statement, Conference of States Parties and Signatories of Treaties That Establish Nuclear-Weapon-Free Zones, Tlatelolco, Mexico, April 26. Available: https://www.iaea.org/newscenter/statements/nuclear-weapon-free-zones-pursuingsecurity-region-region [May 18, 2020].

11 For the content of the annexed protocols of the NWFZ-agreements and the dates of ratifications see NPT Briefing Book by Simpson, John and Elbahtimy, Hassan (eds.) (2018) NPT Briefing Book, James Martin Center for Nonproliferation Studies, Middlebury Institute of International Studies at Monterey.
The Mongolian Nuclear Weapon-Free zone is a special case of a single-country NWFZ [14]. Located between two nuclear weapon states the state, before independence, hosted Soviet military bases. At the time of the withdrawal of the Soviet/Russian bases the country declared, in 1992, its territory a NWFZ. Mongolia's status as a nuclear-weaponfree zone was confirmed by the United Nations in 1998 [15]. In the case of Mongolia there is a Joint Declaration of the P5, which only refers to the negative security assurances the five have given, in the context of the NPT to the non-nuclear NPT members in $1995 .^{12}$

The legal status of these assurances is in doubt. It is claimed that these statements express only an intention and that these commitments are not legally binding. The U.S., for example, does not consider these guarantees as "international agreements" [16]. In the case of the African treaty the State Department and the Pentagon disagreed on whether or not to sign. The Pentagon was reluctant to accept any limitations on its use of nuclear weapons. The U.S. signed the treaty but accompanied it with a declaration that it would not "limit options available to the US if attacked by an African country with weapons of mass destruction". [17] The U.S, has so far not ratified the protocol.

\section{The Mexican Amendments}

In the spring of 1968 , during the final negotiations of the NPT, Mexico, leading the Latin American states, proposed a number of changes to the final NPT text. These "Mexican amendments," as they came to be known, sought several objectives. First, they supported moving disarmament from a mere intention in the preamble as an independent article of the NPT. Second, they sought to revise the article on peaceful uses to include both technical assistance and peaceful nuclear explosions. Lastly, they demanded that the NPT not hinder the formation of NWFZs. The statement on this should be moved from the preamble to an independent article [18].

The Latin American states were concerned, at the time, not only about the Cuban Missile Crisis, but also about the nuclear-weapon programs of Brazil and Argentina. ${ }^{13}$ Independent of the NPT process, twenty-one Latin American states had negotiated the first-ever treaty on a nuclearweapon-free zone (in a populated area). The Treaty of Tlatelolco signed on February 14, 1967 created a nuclear-

12 Joint Declaration by the People's Republic of China, France, the Russian Federation, the United Kingdom of Great Brittain and Northern Ireland, and the United States of America on Mongolia's Nuclear-Weapon-Free Status, 17 September 2012.

13 Both Argentine and Brazil had nuclear weapons programs, as each state sought, not to threaten one other, but to gain prestige to their unpopular military regimes. When the civilian rule returned to both countries, one of the priorities was to get rid of their parallel nuclear programs. Initiated by the Cuban missile crisis the first UN resolution to denuclearize Latin America was introduced by Brazil, which later led to the Treaty of Tlatelolco signed in 1967 and ratified in 1977, for more see: Cronberg, Tarja (2010: 76-78) Nuclear-Free Security. Refocusing Nuclear Disarmament and the Review of the Nuclear Non-Proliferation Treaty, The Finnish Institute of International Affairs, FIIA Report 2010, 21. 
weapon-free-zone in Latin America. ${ }^{14}$ The nuclear-weapon states (P5) were expected to sign an annexed protocol, where they would give a negative security guarantee not to attack any state in the zone with nuclear weapons. All the other ratified this protocol, but the U.S. initially refused to sign. ${ }^{15}$ Nevertheless, weary of losing the votes of the twenty-four Latin American states in the approval process for the NPT in the UN, it ultimately decided to sign and ratify [19].

The Latin Americans collectively succeed in achieving changes in the NPT while also acquiring negative security guarantees from the P5. According to the Secretary of State Dean Rusk, ratifying the treaty of Tlatelolco was the first time the U.S. voluntarily limited its "freedom of response with nuclear weapons." 16 Rusk concluded that "The circumstances present in Latin America are such as to justify a departure from our past policy (...)" [20]. Latin Americans organized as a NWFZ could leverage their common position and their numbers and thus pressure the U.S. to approve the protocol in exchange for support to the NPT. ${ }^{17}$

The Mexican amendments is an exceptional case where the states of a newly established nuclear weapon-free zone were able to change a superpower's behavior and policy. As indicated by Dean Rusk, the U.S. accepted, for the first (and so far the only) time unambiguous limitations to its power to use its nuclear weapons. Could the NWFZ states use this model to get unconditional, legally binding security assurances? How would they achieve the political leverage necessary to change the NPT- treaty to include such assurances and in doing so guarantee their legally-binding status?

\section{The Politics of Changing the NPT}

The NPT has been changed only once in its lifetime. The treaty was approved in 1970 for a trial period of 25 years. In 1995, the indefinite extension of the NPT was agreed on the basis of a compromise package that included approval of

14 The Antarctic had been declared a NWFZ before this.

15 While the US supported the planned NWFZ in Latin America there were reservations not only on the security guarantees but also on the US territories participating, on transit and on the need to prohibit all nuclear explosions. Furthermore, the US underlined that all states of the region should participate. Cuba signed first in 1995 and ratified in 2002. For more see: Foster, William C. (1965) "Letter From the Director of the Arms Control and Disarmament Agency (Foster) to the Chairman of the Negotiating Committee of the Preparatory Commission for the Denuclearization of Latin America (Garcia Robles), in Washington, December 10, 1965", in: Gerakas, Evans; Patterson, David S. and Yee, Carolyn, B. (eds.) (1997) Foreign Relations of the United States, 1964-1968, Volume XI, Arms Control and Disarmament, United State Department of State, Office of the Historian, Washington: United States Government Printing Office.

16 The statement was made by Dean Rusk when he counciled President Johnson to inform the visiting Mexican president in the White House that the US intended to sign Protocol II on the negative security guarantees, for more see: Hunt, Jonathan (2017: 190) Mexican nuclear diplomacy, the Latin American nuclearweapon-free zone and the NPT grand bargain, 1962-1968, in: Popp Roland, Horowitz Liviu and Andreas Wenger (2017) Negotiating the Nuclear Proliferation Treaty. Origins of the nuclear order. Routledge: Milton Park, Abingdon.

17 For a more detailed analysis of the process see Cronberg, Tarja (2021: 82-83) Renegotiating the Nuclear Order: A Sociological Approach, Routledge: Milton Park, Abingdon. multilateral agreements such as the Comprehensive Test Ban Treaty (CTBT), a Fissile Materials Cut-Off Treaty (FMCT), and the convening of a Middle East WMD-Free Zone conference. None of these initiatives has been fully implemented.

Article VIII of the NPT defines how to change the treaty. Any party to the treaty may propose amendments and the text must be submitted to the Depositary Governments (Russia, the UK and the US), which shall circulate it to all signatories. If requested by one-third or more, the Depositary Governments shall convene a conference, with all the parties invited, to consider the amendment. To be approved, an amendment must satisfy three conditions. First, a majority of state parties must vote for it. Second, all nuclear weapon states (P5) must vote for it. Third, all members of the Board of Governors of the IAEA must vote for it. Thus, the NPT cannot be changed without the acceptance of each of the P5.

While the international rules of the NPT are difficult, if not impossible, to change the state parties to the treaty are able to express their discontent by not approving a final document from the review conferences. This has happened regularly at almost half of the review conferences. The lack of the final, consensus document has not had any impact on the support to the treaty but has created a debate on whether a consensus document is needed or not. ${ }^{18}$

A stronger protest could be developed, if a group of member states would walk out of the review conference - or rather threaten to walk out of the review process. A collective walkout has so far never happened. The first ever walk-out from a Review Conference took place when Egypt walked out in 2015 after its proposal for the conference on the WMD-free zone in the Middle East was rejected. "We cannot continue to attend meetings and agree on outcomes that do not get implemented, yet to be expected to abide by the concessions we gave for this outcome" said an Egyptian delegation representative before walking out of the meeting. He referred to the 1995 decision to make the NPT permanent conditioned to progress on the resolution on the WMD zone [21].

A walk out by a single nation in support of a zone, such as in the case of Egypt, is not enough. A walk-out by a majority of the signatories of the NPT treaty would have a different impact. If a state would walk out, this would no doubt be criticized in strong words by the international community, which also would refer to the state's potential interest to access nuclear weapons. This would not be the case for the NWFZ-states due to their double commitment. Even if formally leaving the NPT, their regional commitment to the nuclear-free status would still prevail as signatories of the regional treaties.

Harries (2015) has rightly pointed out that a walk-out of

18 For the debate on whether consensus was misleading as states do not come up with their objections or whether abolishing the consensus principle would be undemocratic and favour the West see: Dhanapala, Jayantha (2016) Who Is Afraid of Consensus? The NPT Review Process, Issue Brief, James Martin Center for Nonproliferation Studies, Monterey: Middlebury Institute for International Studies and Einhorn, Robert (2016) "The NPT Review Process: The Need for a More Productive Approach”, Arms Control Today, September. 
the review process is only a theoretical possibility, as long as "the widespread security benefits of continued nonproliferation" exist. Nevertheless, he asks the question "whether dissatisfaction of the slow pace of disarmament will create political momentum that cannot be contained, with detrimental side-effects for the NPT." [22]. My question today is whether the combination of the new treaty, the TPNW, and the current modernization plans of the nuclear weapon states have created such a momentum, at least a momentum strong enough for the NWFZ-states to walk out of the process unless unconditional, legally binding negative security assurances are guaranteed, at least for all these states with a double commitment to a nuclear-free status.

Under which conditions could the NWFZ-states successfully carry out a walk out and get the negative security assurances on the NPT-agenda, in spite of the veto power of the P5?

\section{A Global Alliance}

The NWFZ-states are well-organized regionally with a common regional treaty in the background. These treaties, although there are some variations in the restrictions they pose, are similar enough to create a common NWFZ-identity. However, these regional zones do not have a global organization and they have no experience of collective action at the NPT Review Conferences.

Nevertheless, there have been efforts to increase global cooperation among the zones. The Vienna Centre for Disarmament and Non- Proliferation, VCDNP, organized a Task Force in 2017 to increase cooperation among the existing zones. The Task Force gave recommendations on how to increase cooperation in fields such as information/communication, research and disarmament, and non-proliferation [23]. Notably, the Task Force did not offer recommendations on how these zones could better defend their common interests and goals in the nuclear order, such as how to achieve the P5 ratifications of their negative security assurances.

The NWFZ-states in the five regions and Mongolia theoretically have the potential leverage as they form the majority of the states and have a double commitment to a nuclear weapon-free status. They could take "the Mexican amendments" to another level by threatening the nuclear weapon states with a walk-out. They would have to be united enough in demanding the ratification of the security protocols in the zone treaties or, in order to make them legally binding to become a modification of the NPT-text itself. As the nuclear weapon states defend the survival of the NPT this could be a possible bargain to achieve the unconditional negative security assurances and at the same time supporting the superpowers' interest of the NPT (and their right to remain nuclear weapon states as defined by the NPT).

Unconditional security guarantees would have to be enforced and their legality guaranteed. They should not be subject to a reinterpretation depending on the political situation as in the Ukraine case.

\section{Non-Nuclear States Outside the Zones}

Assuming that the NWFZ- states collectively could achieve to change the NPT, the question now becomes what about the other non-nuclear states outside the regional zone treaties. There is no obvious model for a region to become a nuclear-free zone if one or several of the region's states are nuclear and unwilling to renounce their weapons. Nevertheless, a number of former nuclear weapon states are members of a zone. South Africa decided to abolish nuclear weapons and later became a party to the African zone. After the collapse of the Soviet Union the nuclear weapons from Kazakhstan, Ukraine and Belarus were moved to Russia. After this Kazakhstan has been instrumental in creating the Central Asia zone.

One of the more doctrinal past cases is the question of Argentine and Brazil. Although the two states did not yet have nuclear weapons, both had a nuclear program. The aspirations of these two countries to become nuclear weapon states were more symbolic than strategic in nature. More than seeking to threaten one other, each state sought to enhance its position on the world scene and gain legitimacy for their unpopular military regimes. When the civilian rule returned, in both countries by the late 1980s, one of the priorities for their civilian leaders was to get rid of their parallel nuclear programs and to implement the IAEA safeguards [24].

Both in the past and in the current debate proposals have been made for a zone, where one or more states have nuclear weapons. A special case is the Middle East zone [25], which covers all of the weapons of mass destruction. It has been an object of analysis due to its strategic importance for the 1995 decision to make the NPT permanent. A yearly conference on the issue is to take place at the UN. Also, potential future nuclear-weapon-free zones have been discussed such as Northeast Asian NWFZ [26], the South Asian NWFZ, and even European nuclear-weapon-free zone [27].

The European model has been based on subregional zones as the first step. In order to go around the formerly two, now one nuclear weapons state in Europe, it has been proposed that, in the first phase, only parts of Europe will declare themselves as a nuclear-weapon-free zone [27]. In Northeast Asia, there are plans by non-state actors to develop a zone based on a model of $3+3$. The three states of the nuclearweapon-free zone would be North Korea, Japan, and South Korea. The three other states, Russia, China, and the U.S., would collectively guarantee the security of the zone. In July 2013, the UN Advisory Board on Disarmament recommended to the United Nations Secretary-General to "take action towards establishing an NEA-NWFZ", which was originally a Japanese idea [28].

A further model, opening up the concept for any state seeking to formalize its nuclear-free status, is the Mongolian NWFZ. Mongolia, sandwiched between two superpowers with nuclear weapons is a special case, but its status as a NWFZ paves the way for other states to choose the same path. Thus, a single state NWFZ is not only a Mongolia related issue. It has already been discussed in Sri Lanka and Iceland and is an obvious solution in 
cases, where a state is surrounded by vast sea areas. The model should be included as a distinct possibility in special cases in spite of the P5 reluctance to accept and issue security assurances to single state-NWFZ [14].

Finally, the most difficult case is the one of South Asia with two nuclear weapon states hostile to each other. In 1978, Pakistan made a proposal to limit the nuclear race between two countries and to establish the South Asia NuclearWeapon-Free Zone. However, negotiations were never concluded [29]. Today, the two countries are on the brink of war, potentially even a nuclear war.

New innovative models are needed to solve the problem of how to create NWFZs in regions with one or more nuclear states. These may be different for the different zones. The examples above already illustrate that the idea of a nuclearweapon-free zone is adaptable. The zones can learn from each other. The European model of creating sub-regions as a first step, could be applied in the MENA region as well. The Northeast Asian model could be an adaptable model for regions, where one or several of the superpowers are involved.

\section{A Nuclear-Weapon-Free World}

The nuclear weapon-free zones already cover the majority of the states and a third of the world's population. It is time to ask the question, how could the number be increased to cover the world. Is a world of these zones even a theoretical possibility today? A number of authors have focused on this particular question, namely whether these zones could be seen as steppingstones to a nuclear-weapon-free world [30].

An example of this approach is presented by the Ambassador Thomas Graham in his book on "The Alternate Route". Here the long-time U.S. ambassador on nuclear arms control and disarmament looks at each of the nuclear weapon-free zones and explores the possibility of expanding these zones to eventually encompass the entire world, region by region. In his words: "An alternative route to nuclear disarmament is needed. The nuclear weapon-free zone (NWFZ) movement, little heralded in conferences on nuclear policy around the world, might be such an alternative." [31].

The critical question is the role of the superpowers. Nuclear weapons are seen as the currency of power in international relations [32]. A superpower, projecting world power, would hardly agree to become a non-nuclear member of a zone. It is unthinkable that the U.S. or China would ever voluntarily give up their nuclear weapons and become members of their regional zones respectively. Nevertheless, ambassador Graham is optimistic and his approach is one of linking the possible future zones and the superpower situation together. According to him:

"If someday in the long term future these regions (the Middle East, northeast Asia and South Asia) could move in the direction of becoming nuclear-free areas, the remaining areas - China, Russia and the states of the North Atlantic Treaty Organization (NATO) - might then become nuclear weapon-free themselves, bringing into a successful conclusion the long term effort to achieve the complete elimination of nuclear weapons worldwide. Thinking about, examining and perhaps pursuing this process is a tall order, but it is far better than putting aside the ultimate objective of a stable, verifiable, nuclear-weapon-free world." [33].

\section{Conclusions}

In "Renegotiating the Nuclear Order" [4] I have documented the unbalance between the rights and obligation between the nuclear and non-nuclear states, as requested in a UN resolution in 1965. During the past 50 years the balance has been radically distorted. The nuclear weapon states consider their right to deter as permanent and maintain their right to attack even the states that have abstained under certain conditions. The security of the non-nuclear states is undermined by this calculated ambiguity built into the process of defining nuclear threats.

Unconditional, legally binding negative security guarantees would be a step towards reestablishing a more reasonable balance. As the nuclear weapon states have the right to deter, it would be just and fair that the states that have abstained -and particularly the states that have a double commitment to a nuclear-free status like the NWFZ-stateswould not, under any conditions be subject to a nuclear attack. As a minimum for these states the calculated ambiguity related to a nuclear attack must be reduced to a minimum, with time to zero.

Legally binding negative security assurances would have to be established in a legally-binding international agreement, preferably in the NPT. To do this would require that the treaty be modified or renegotiated. This in turn, would require a strong manifestation by the NWFZ-states in the form of a walk-out of the NPT Review Conference. This is achievable only if the NWFZ-states are able to show a global commitment and coordination.

Unconditional, legally-binding security assurance integrated into the NPT would increase the attractiveness of belonging to a NWFZ and would potentially increase the prestige on the international scene of these zones. As they gradually would limit the space available for deterrence, this could also initiate a process by the superpowers as indicated above by Ambassador Thomas Graham.

\section{References}

[1] United Nations General Assembly (UNGA) (2017) Treaty on the Prohibition of Nuclear Weapons (TPNW), A/CONF.229/2017/8, July 7. Available: http://undocs.org/A/CONF.229/2017/8 [December 17, 2018] United Nations Office for Disarmament Affairs (UNODA) (2020) Treaty on the Prohibition of Nuclear Weapons: The Status of the Treaty, [Online]. Available: http://disarmament.un.org/treaties/t/tpnw [July 12, 2021].

[2] Reaching Critical Will, Negative security assurances, A Fact Sheet. http://www.reachingcriticalwill.org/resources/factsheets/critical-issues/5442-negative-security-assurances [29.12.2018]. 
[3] Schelling, Thomas (1966) Arms and Influence, New Haven: Yale University Press.

[4] Cronberg, Tarja (2021) Renegotiating the Nuclear Order: A Sociological Approach, Routledge: Milton Park, Abingdon.

[5] Willrich, Mason (1966) "Guarantees to Non-Nuclear Nations", Foreign Affairs, July 1966.

[6] United Nations Security Council (UNSC) (1995) Security assurances against the use of nuclear weapons to non-nuclearweapon States that are Parties to the Treaty on the NonProliferation of Nuclear Weapons, Resolution 983, 11 April. Available: http://unscr.com/en/resolutions/984 [28.12.2018].

[7] NPT Review Conference (1995) Annex II: Unilateral security assurances by nuclear-weapon States, 1995 Review and Extension Conference of the Parties to the Treaty on the Non-Proliferation of Nuclear Weapons, NPT/CONF. 1995/6, 15 March. Available: http://www.un.org/Depts/ddar/nptconf/2162.htm [December 29, 2018].

[8] The State Council Information Office of the People's Republic of China (2019) China's National Defense in the New Era, July 2019, Foreign Languages Press Co. Ltd., Beijing. Available: http://www.xinhuanet.com/english/201907/24/c_138253389.htm [May 18, 2021].

[9] The Basic Provisions of the Military Doctrine of the Russian Federation, 2 November 1993 https://fas.org/nuke/guide/russia/doctrine/russia-mil-doc.html [July 12, 2021] Sokov, Nikolai (1999) Russia's 2000 Military Doctrine, October 1, Nuclear Threat Initiative. Available: https://www.nti.org/analysis/articles/russias-2000-militarydoctrine/ [July 12, 2021] The Military Doctrine of the Russian Federation, Approved by the President of the Russian Federation on December 25, 2014, No. Pr.-2976. Available: https://www.rusemb.org.uk/press/2029 [July 12, 2021].

[10] Gerson, Michael S. (2010: 9) "No First Use: The Next Step for U.S. Nuclear Policy”, International Security, 35: 2, 7-47.

[11] Cartwright, James E. and Blair, Bruce G. (2016) "End the First-Use Policy for Nuclear Weapons", The New York Times, 14 August.

[12] Perry, William J. and Schlesinger James R. (2009) America's Strategic Posture the Final Report of the Congressional Commission on the Strategic Posture of the United States, Washington D.C.: United States Institute of Peace Press.

[13] Budjeryn, Mariana (2014) The Breach: Ukraine's Territorial Integrity and the Budapest Memorandum, Wilson Center, Nuclear Proliferation International History Project, Issue Brief No. $3, \quad 3 \quad$ September. Available: https://www.wilsoncenter.org/publication/issue-brief-3-thebreach-ukraines-territorial-integrity-and-the-budapestmemorandum [July 12, 2021].

[14] Enkhsaikhan, Jargalsaikhan (2021) Time to Think Beyond Current NWFZs, IND - InDepthNews, 30 April. Available: https://www.indepthnews.net/index.php/opinion/4410-time-tothink-beyond-current-nwfzs [July 12, 2021] Enkhsaikhan, Jargalsaikhan (2005) "Mongolia - A Model for an Innovative Approach to Nuclear-Weapon-Free Zones", The Nonproliferation Review, Volume 12, Issue 1, pp. 153-162.

[15] United Nations General Assembly (UNGA) (1998) Mongolia's international security and nuclear-weapon-free status, 53/77 $\quad$ D. Available: https://gafc-
vote.un.org/UNODA/vote.nsf/91a5e1195dc97a630525656f00 5b8adf/96c2fbb213c0d34f052566be005e2bfc?OpenDocument \#_Section5 [April 6, 2021].

[16] Bunn, George (1997: 12) "The legal status of U.S. negative security assurances to non-nuclear weapon states", The Nonproliferation Review, Spring-Summer 1997. Available: http://nautilus.org/wp-content/uploads/2011/12/bunn43.pdf [29.12.2018].

[17] Schell, Jonathan (2007: 99) The Seventh Decade: The New Shaoe of Nuclear Danger, New York: Metropolitan Books.

[18] Hunt, Jonathan (2017: 188) "Mexican nuclear diplomacy, the Latin American nuclear-weapon-free zone and the NPT grand bargain, 1962-1968", in: Popp Roland, Horowitz Liviu and Andreas Wenger (2017) Negotiating the Nuclear Proliferation Treaty. Origins of the nuclear order, Routledge: Milton Park, Abingdon.

[19] Hunt, Jonathan (2017: 186) "Mexican nuclear diplomacy, the Latin American nuclear-weapon-free zone and the NPT grand bargain, 1962-1968", in: Popp Roland, Horowitz Liviu and Andreas Wenger (2017) Negotiating the Nuclear Proliferation Treaty. Origins of the nuclear order, Routledge: Milton Park, Abingdon.

[20] Rusk, Dean (1968) "Memorandum from Secretary of State Rusk to President Johnson in Washington, February 12, 1968", in: Gerakas, Evans; Patterson, David S. and Yee, Carolyn, B. (eds.) (1997) Foreign Relations of the United States, 19641968, Volume XI, Arms Control and Disarmament, United State Department of State, Office of the Historian, Washington: United States Government Printing Office. Available: https://history.state.gov/historicaldocuments/frus1964$68 \mathrm{v} 11 / \mathrm{d} 226$ [July 21, 2020].

[21] Reaching Critical Will (2014: 7) The NPT Action Plan March 2014. Available: http://www.reachingcriticalwill.org/images/documents/Publicatio ns/2010-Action-Plan/NPT_Action_Plan_2014.pdf [3.7.2021].

[22] Harries, Matthew (2015: 5) Disarmament as Politics, Lessons from the Negotiation of NPT Article VI, Chatham House the Royal Institute of International affairs, London.

[23] Vienna Center for Disarmament and Non-Proliferation (VCDNP) (2018) Cooperation among Nuclear-Weapon-Free Zones: History, Challenges and Recommendations, VCDNP Task Force Report, March. Available: https://vcdnp.org/wpcontent/uploads/2018/03/NWFZ-TF-Report-final-1.pdf [May $15,2020]$.

[24] Cronberg, Tarja (2010: 77-78) Nuclear-Free Security. Refocusing Nuclear Disarmament and the Review of the Nuclear Non-Proliferation Treaty, The Finnish Institute of International Affairs, FIIA Report 2010, 21.

[25] Shaw, B. Douglas (2012) "Middle East Nonproliferation - Toward a Zone of Inclusion", The Nonproliferation Review, Volume 19, Issue 3, pp. 357-363. United Nations General Assembly (UNGA) (2016) First Committee Sends 22 Texts to General Assembly, Echoing Call for Expanding Nuclear-Weapon-Free Zones into Middle East, Bolstering Disarmament Efforts, Meetings Coverage, General Assembly First Committee, Seventy-first Session, 22nd Meeting (PM), GA/DIS/3563, October 27. Available: https://www.un.org/press/en/2016/gadis3563.doc.htm [July 21, 2020].

[26] Liping, Xia (1999) "Nuclear-weapon-free zones: Lessons for nonproliferation in Northeast Asia", The Nonproliferation Review, Volume 6, Issue 4, pp. 83-92. 
[27] Müller, Harald; Franceschini, Giorgio; Melamud, Aviv; Müller, Daniel; Péczeli, Anna; Schaper, Annette (2015) A Nuclear Weapon-Free Zone in Europe. Concept-Problems - Chances, Peace Research Institute Frankfurt, 23 April.

[28] Enkhsaikhan, Jargalsaikhan (2019) Establishment of a Nuclear-Weapon-Free-Zone in Northeast Asia, 1 October. Available: https://medium.com/perspectives-on-peace-andsecurity-in-a-changing/establishment-of-a-nuclear-weaponfree-zone-in-northeast-asia-d610c4f44f6b [3.7.2021].

[29] Akram, Munir (2016) "Pakistan's nuclear diplomacy", Dawn, June 26. Available: https://www.dawn.com/news/1267269 [July 12, 2021].

[30] Thakur, Ramesh (1998) "Stepping Stones to a NuclearWeapon-Free World”, in: Thakur, Ramesh, (Ed.), (1998)
Nuclear Weapons-Free Zones, Palgrave Macmillan, London, 10.1007/978-1-349-26972-3. Graham, Thomas (2017) The Alternate Route, Oregon State University Press: Corvallis.

[31] Graham, Thomas (2017: 1) The Alternate Route, Oregon State University Press: Corvallis.

[32] Harrington de Santana, Anne (2009) "Nuclear weapons as the currency of power: Deconstructing the Fetishism of Force", The Nonproliferation Review, 16: 3, 325-345.

[33] Graham, Thomas (2017: 2) The Alternate Route, Oregon State University Press: Corvallis. 